\title{
Eski Türkçedeki “ḳı” sözcüğünde fono-semantik durum
}

\section{İbrahim KEKEVI'1}

APA: Kekevi, İ. (2020). Eski Türkçedeki “kıı" sözcüğünde fono-semantik durum. RumeliDE Dil ve Edebiyat Araştırmaları Dergisi, (20), 157-166. DOI: 10.29000/rumelide.791119.

\section{$\ddot{0} \mathbf{z}$}

Eski Türkçede fonolojik ve semantik hususlar bugünkü Türk dili için önemli referans verileri içermektedir. Türk dilinin tarihi devirlerini belirlemede farklı görüşler bulunmaktadır. Eski Türkçe için hakim görüş, Orhon Türkçesi döneminden Harezm döneminin sonuna kadar olduğu yönündedir. Bu kapsam içinde artsüremli olarak değerlendirilen sözcüklerden biri kız sözcüğüdür. Eski Türkçe dönemi içinde $k l z$ sözcüğünün bir anlam genişlemesine uğradığı ve bu dönemin sonlarında tekrar daralmaya uğradığı yönünde yaygın bir kanı bulunmaktadır. Dilin üç temel yönü olarak görülen yapı, anlam ve bildirişim unsurlarının birbirleriyle ilişkili olduğu da dikkate alınmalıdır. İşte bu noktada sözcüğün fonolojik yönü de değerlendirilmeli ve tespit teyit edilmelidir. Bu doğrultuda konu üzerine kavram karmaşası olmaması adına çok anlamlılık, eşadlılık ve eşanlamlılık kavramları üzerine bilgiler paylaşılmıştır. Bilgiler doğrultusunda kaynak metinlerden yapılan tespitlerin fonolojik yönü değerlendirilmiştir. Kaynak eserler üzerinden bakıldığında semantik hususlar, anlam genişlemesiyle açılanamayacak niteliktedir. Anlam bilimciler bu tip durumları anlam bulanıklığı olarak açıllamaktadırlar. Anlam genişlemesi sürecinin Türk dilinde büyük ölçüde benzetme ve somuttan soyuta aktarım yoluyla geliştiği göz önüne alındığında burada böyle bir gelişim olmadı̆̆ı görülmektedir. Elde edilen veriler ışı̆̆ında kız sözcüğü üzerine benimsenmiş olan anlam genişlemesi ve daralması tespiti, tartışmaya açıktır. Sözcüğün yazımı, ünlü uzunlukları meselesi dikkate alındığında bir kökteşlik, eşadlılık ya da ünlülerin uzun veya kısa yazımının zaman içinde dikkate alınmamasının yarattığı anlam bulanıklığı bu sözcük üzerine değerlendirilmesi gereken konulardır.

Anahtar kelimeler: Kız, fono-semantik, eş anlamlılık, eşadlılık(eşseslilik), kökteşlik

\section{Phono-semantic situation in the old Turkic "ḳı" word}

\begin{abstract}
Phonological and semantic issues in Old Turkic contains important reference data for today's Turkish language. There are different opinions in determining the historical periods of the Turkic language. The dominant view for Old Turkic is that it is from the period of Orkhon Turkish to the end of the Harezm period. Within this scope, one of the words evaluated as artifacts is the word kaz. There is a widespread belief that the word $k z z$ underwent a meaning widening in the old Turkic period and that it contracted again at the end of this period. It should also be taken into account that the structure, meaning and communication elements, which are seen as the three main aspects of language, are interrelated. At this point, the phonological aspect of the word should also be evaluated and the determination should be confirmed. Accordingly, information was shared on the concepts of multisignificance, synonymity and synonym in order to avoid confusion on the subject. In line with the information, the phonological aspects of the determinations made from the source texts were
\end{abstract}

1 Arş. Gör., İnönü Üniversitesi, Fen Edebiyat Fakültesi, Türk Dili ve Edebiyatı Bölümü (Malatya, Türkiye), ikekevi@gmail.com, ORCID ID: 00oo-0003-0554-1052 [Makale kaytt tarihi: 02.08.2020-kabul tarihi: 20.09.2020; DOI: 10.29000/rumelide.791119] 
evaluated. When looking at the source works, semantic issues are inexplicable with the expansion of meaning. Semanticist describe such situations as blurring of meaning. Considering that the process of meaning expansion has developed in Turkic language to a large extent by analogy and from concrete to abstract, there is no such development here. In the light of the data obtained, the detection of the meaning expansion and contraction adopted on the word $k z z$ is open to discussion. Considering the spelling of the word and the vowel lengths, it is the subjects that need to be evaluated on this word.

Keywords: Kız, phono-semantic, synonymity, homonymity, cognate

\section{Giriş}

Türk dili, tarihî dönem metinlerinde söz varlığı bakımından zengin bir veri kaynağı olmanın yanı sıra mevcut sözcüklerin çok anlamlılığı ve işlevsel oluşu bakımından da zengindir. Çok anlamlılık durumu, sayısız örnekte görüldüğü üzere çoğunlukla birbiriyle anlam açısından bir mantık ilgisi kurulacak şekilde gelişmiştir.

Türk dilinin her döneminde önemli ölçüde görülen "kız" sözcüğü için artsüremli bir bakış açısıyla şöyle bir açıklama getirilmiştir: Eski Türkçe dil devresinden beri takip edilen bu kelime "kız, evlenmemiş, kadın, cariye" anlamlarının yanı sıra orta Türkçe ile birlikte "nadir, pahalı, kıymetli, değerli, kıt, az bulunan, kıtlık, nadirlik" gibi anlamları da taşımıştır. Bu yönüyle kelimede bir anlam genişlemesi olduğu söylenebilir. Eski Anadolu Türkçesi eserlerinde her iki anlamda da kullanılan kelimenin ikinci sıradaki "nadir, pahalı, kıymetli, değerli, kıt, az bulunan, kıtlık, nadirlik" anlamı birinci anlama nazaran daha az kullanılmakla birlikte kelime "pahalı, nadir, az, kıt" anlamını Clauson'un da belirttiği üzere "kut" kelimesine bırakmış (1972:680) diğer birinci anlam olan "kız, evlenmemiş, kadın, cariye" ise anlam daralması ile "kız, evlenmemiş kadın" olarak anlamlandırılmıştır(Üşenmez 2014:426). Eski Türkçede "kız evlat" için kullanılan sözcük; Orta Türkçede "pahalı, değerli şey, cariye, gelin, kadın, kız" gibi anlamlar kazanarak anlam genişlemesine uğramıştır. Sözcük daha sonra Kırgız Türkçesinde anlam kötüleşmesine uğrayarak "dişi köleler" anlamında kullanılmaktadır. Sözcük diğer çağdaş Türk lehçelerinde ise "genç kız, kız evlat, bakire” anlamlarıyla yaşamaktadır(Yıldırım 2020:1767).

Anlam genişlemesi ve daralması yönündeki açıklama iki yönden sınanmalıdır. Birincisi sözlük ve metin çalışmalarının dizinlerinin dahi iki ayrı madde başında değerlendirdiği sözcük, kökteş ya da iki ayrı sözcük olabilir. İkincisi çok anlamlılık ya da anlam genişlemesinin gelişim mahiyetine göre çok anlamlı görülen bu göstergenin sınanması gerekir. Bu doğrultuda ele alınacak metodolojik kavramlara ilişkin bilgileri vererek başlamak yerinde olacaktır.

Çok anlamlılıkta gösterge temel anlamını yitirmeden yan anlamlar kazanmaktadır. Zaman içinde bunlar unutulabildiği gibi yeni yan anlamlarla daha da zenginleşebilmektedir(Aksan 2017:90). Çok anlamlılıkta bir göstergenin, temel anlamının yanı sıra, onunla mutlaka ilişkisi bulunan yeni yeni anlamlar kazanması söz konusudur. Eşadlılıkta ise birbiriyle anlamca ilgisi bulunmayan kavramlar, bir rastlantı ya da kimi zaman yabancı bir dilden alınan öğelerle eşlik nedeniyle aynı göstergeyle anlatılır duruma gelmiş olabilir. Eşadlılık, bir dil içinde birbirinden bütün bütün ayrı iki ya da daha çok kavramın ses ya da yazım açısından aynı nitelikteki göstergelerle dile getirilmesidir. Bugün Türkçede sesçil bir yazım kullanılmakta ve yazımdaki eski biçimler genellikle yazıya yansıtılmamaktadır(Aksan 2017:92). Bir dil içinde eşadlılığın oluşmasında genel olarak iki etken ileri sürülebilir. Bunlardan birincisi, farklı anlamdaki iki ya da daha çok sözcüğün, zaman içinde geçirdikleri ses ya da biçim değişikliği nedeniyle 
birbirlerine yaklaşması, sesteş duruma gelmeleridir. Eşadlılığa neden olan ikinci etken, yabancı dilden alınan bir sözcüğün yerli dildeki bir başkasıyla sesteş olarak birlikte yaşar duruma gelmesidir.(Aksan 2017:93). Çok anlamlılık konusunu işlerken belirttiğimiz gibi, kimi dilciler bu konuyla eşadlılı̆̆ anlam bulanıklığı çerçevesi içinde ele almaktadırlar. Ancak orada da belirttiğimiz üzere, bütünüyle ayrı kavramları dile getiren eşadlıların bir anlam bulanıklığına ve anlaşılmazlığa yol açması genellikle söz konusu değildir. Çünkü belli bir metnin bağlamı ve konusu içinde bu kavramlardan hangisinden söz edildiği kendiliğinden anlaşılır. Kaldı ki çok anlamlılıkta bir göstergenin yansıttığı kavramların hangisinin kastedildiği, bağlama bakılarak kolaylıkla aydınlanır(Aksan 2017:94).

Dilbilimde genellikle benimsenen bir yargı, hiçbir dilde, başlangıçta, bir kavramı yansıtmak için birden çok göstergenin kullanılamayacağı biçimindedir. Bir başka deyişle, aynı dilde iki ayrı gösterge bütünüyle aynı anlama gelemez. Bu gerçek N. Goodman tarafından mantık açısından da kanıtlanmıştır(bkz. Aksan 1975:531-542). Durum böyleyken birbirine yakın anlamlı sözcükler için Yunancada kullanılan sün (birlite, eş) ve onoma (ad) sözcüklerinden kurulu sünônümos terimi bütün dillerde yaygınlaşmıştır(Aksan 2017:99). Aynı kavram alanından, yakın kavramların temsilcisi kimi öğeler genellikle uzun bir süre içinde ve doğal olan anlam olayları sonucunda anlamca eşdeğerli duruma gelebilmektedir(Aksan 1975:3).

\section{Sözlüiklerdeki durum}

Clauson, 'kız' sözcüğünü iki ayrı madde başında değerlendirir. İki maddede de kız sözcüğü uzun ünlülü (kı:z) olarak alınmıştır. İlki için temelde kız, evlenmemiş kadın anlamıyla kullanılırken daha sonra anlam daralmasına uğrayarak 'kız çocuğu, cariye' anlamlarında kullanıldığını belirtir. Kâşgarlı'da kız sözcüğünün uzun ünlülü (kı:z) bir biçimde kullanıldığını ve bugün Türkmencede de (gl:z) aynı uzunluğun korunduğu bilgisini verir (ED 679b). İkinci için temel olarak 'maliyetli, pahalı, nadir ve cimri' anlamlarında kullanıldığını ve Osmanlı Türkçesinde kıt biçimiyle hala yaşamakta olduğunu belirtir(ED 680a).

Li de Clauson'a atıfta bulunarak sözcüğün ileride de değineceğimiz xīz madde başı için "Kasgarlı, bunun Kıpçakça ve Oğuzca biçim olduğunu belirtmiştir.” notunu düşmüştür(1999:203). Bununla birlikte günümüz Türk lehçelerindeki kullanımlarından bazıları aşağıda verilmiştir:

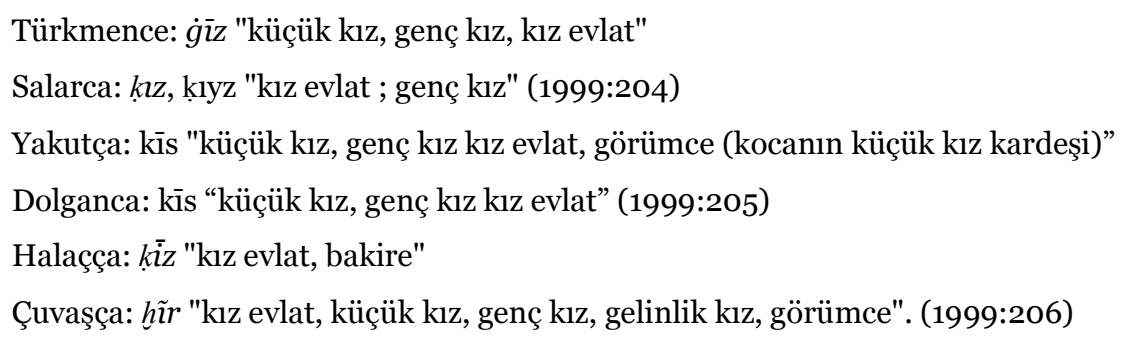

Tekin’in çalışmasında da günümüz lehçelerinden Türkmen Türkçesinde qīz, Yakut Türkçesinde kīs olarak uzunluklarını korudukları bilgisi verilmiştir(1995:84). Drevnetjurkskij'de fonetik ayrım yapılmaksızın qïz maddesine $1 \mathrm{kız}$, bakire; 2 pahalı, değerli; 3 paragöz, açgözlü anlamları verilmiştir(Nadalyayev vd 1969:449,450). Eski Uygur Türkçesinde de kız sözcügünün iki farklı anlama gelecek şekilde kullanımı görülmektedir. Caferoğlu, sözlük çalışmasında kız sözcüğü için 'sıcak, kız, hasis (cimri)' anlamlarını verir; bunun yanı sıra kız-kız sözcük grubu için 'genç hanım, kız evlat' anlamlarını verir(2015:178). 


\section{Kaynak eserlerdeki durum}

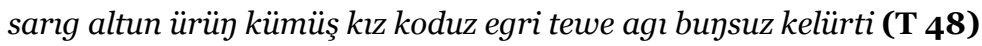

Sarı altın, beyaz gümüş, kızlar (ve) karılar, (tek) hörgüçlü develer, ipeklileri sıkıntısızca getirdiler. (Aydın 2017:116-117)

Tonyukuk yazıtının 48. satırındaki kız sözcüğü “ZPQ" runik karakterlerle yazılmıştır. Sözcüğün yazımında $\imath k$, $k \imath(\mathrm{Q})$ ses (hece) değerlerine karşılık gelen karakterin kullanımının yanında $\imath, i(\mathrm{P})$ seslerinin yazımında kullanılan karakterin de kullanılması ünlü uzunluğunu göstermek için olmalıdır.

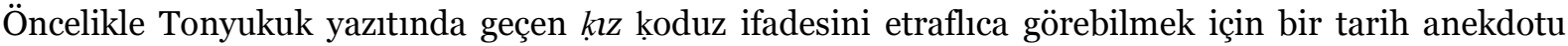
paylaşmakta yarar olacaktır: Kök-Türk "tamğa"sındaki piktogram, kanâatimize göre, Doğu Asyadaki bütün cihangir sülâlelerinin ongunu, kuyruğunu kaldırarak saldıran boğanın, boynuzları arkaya dönük, "kotuz" cinsidir. Dr. O. Sertkaya şu mülâhazayı da ifâde etti: "bu "tamğa", Kök-Türk kitâbelerindeki, dehşet veren hücûmların remzi, "oplayu” (boğa-gibi) tabirinin ifâdesi olsa gerek” . Piktogramın kuyruğunun ucundaki sorguç da, esâsen, bilhassa tebârüz ettirilmiş. Nihâyet, hiç şüphe brrakmayan bir keyfiyet: Oğuz hükümdârı Baz Kağanın oğlunun mezar taşına aynı " tamğa” çizilmiş olup, yanına, KökTürk harfleri ile, “ kotuz” yazılmıştı(Esin 1985:131).

Tonyukuk'ta geçen bu sözcüğün oluşturduğu sözcük grubu ķz koduz için Sertkaya şunları ifade etmektedir: Cümlenin incelediğimiz bölümündeki sarig altun, ürụ̈ kümüş ve egri tebi kelime guruplarının ilk unsuru olan sarı́g, ürüy ve egri kelimelerinin, kendilerinden sonra gelen altun, kümüş ve tebi kelimelerinin sıfatı olduğunu görüyoruz. Bu paralelizmden hareket ederek diyebiliriz ki cümlenin

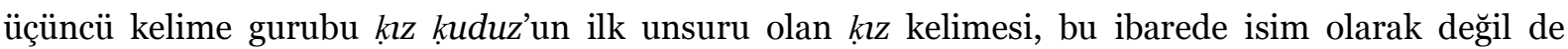
kendisinden sonra gelen ķuduz kelimesinin sıfatı olarak kullanılmıştır(1995:178-179). Bu bağlamda eş değer örnekler de veren Sertkaya, tek tereddütün k $k z$ kelimesinin sıfat olarak 'dişi' manasında insan dışı varlıklar için kullanılıp kullanılamayacağı hususu olduğunu belirtir(1995:179). Tonyukuk yazıtında geçen $k ı z$ koduz ifadesindeki koduz sözcüğünün 'sığır' anlamına geldiğine ilişkin Kaşgarlı'dan ve Kutadgu Bilig'den örnekler(1995:181) veren Sertkaya, sıfat tamlaması olarak değerlendirdiği sözcük grubu için 'kıymetli veya dişi(?) sığır' manasını vermiştir.(1995:182).

Mesele bu noktada koduz'dan hareketle ḳz sözcüğünün 'kıymetli' anlamıla karşılanması olduğu için makalede sırasıyla ilgili cümlede sayılan altın, gümüş, deve adlarıyla birlikte bağlam unsuru da dikkate alınarak incelenmelidir. Tonyukuk yazıtında ganimetler sırasıyla; sarı, beyaz, eğri/hörgüçlü sözcükleriyle nitelenirken sığır sözcüğünün kıymetli sözcüğüyle nitelenmesi olası görünmemektedir. Bu açıdan koduz sözcüğü dul kadın veya sı̆̆ır anlamı da içerse ḳz sözcüğünün 'dişi' anlamı içermesi gerekmektedir.

burguda yètdim törtünç ay tokuz yaฤıka süyüşdüm sançdım yılkısın barmmı kızın koduzun kelürtüm (ŞU D 3)

(Onlara) Burgu (Irmağı)'da yetiştim. Dördüncü ayın dokuzuncu gününde savaştım, mızrakladım. At sürülerini, varlıklarını, kızlarını ve karılarını getirdim.(Aydın 2018:55)

Şine Usu yazıtının doğu yüzünün 3. satırında kız sözcüğü "ZPK” runik karakterleriyle yazılmıştır. Ünsüzlerin kalınlık ve incelik durumu ve kız sözcüğünün koduz sözcüğüyle birlikte kullanılan işlek bir ifade olması ihtimali göz önüne alındığında $\iota, i(\mathrm{P})$ ünlü karakterinin yazımına gerek duyulmayabilirdi ki eski Türk yazıtları ünlü yazımına gerek duyulmamış sayısız örnekle doludur. Kuşkusuz bunu bir tür hece yazısı olmasına yormak mümkündür. 
sakın]ur men tèdi yme èkinti kata satıgçı er yüz altun ayap t(amgala)p kulı el(gint)e ol kızı ıdtı (Mainz 388. No.lu Yazma Parçası)

Düşünürüm dedi. Yine ikinci kez satıcı adam yüz altın takdim ederek (belgeyi) damgalayıp kölesinin eliyle o kızı gönderdi. (Ylldırım 2017:192, 193)

Şine Usu yazıtındaki durum yukarıdaki yazma parçasında da görülmektedir. Tipkı Tonyukuk ve Şine Usu'da olduğu gibi burada da ' kzz' sözcüğü bugünkü anlamıyla kullanılmıştır. Yazma parçasında görüldüğü üzere (Yıldırım 2017:194) sözcüğün yazımı “ZPK” biçimindedir.

Yenisey yazıtlarında E 3/6, E/48/10, E 59/7, E 98/5 numaralı yazıt ve satırlarda geçen kız sözcüğü 'kız' anlamında kullanılmıştır(Aydın 2019:263). Bunlardan E 98/5’te ünlülü yazımı olmamakla birlikte transkripsiyonu kızı böke? biçimindedirAydın 2019:203). Yazımından emin olunamayan bu yazıtın dışındakiler (E 3/6, E/48/10, E 59/7), “ZPK” biçiminde ünlülü yazılmıştır(Aydın 2019:49,156,174).

Berliner Turfan Texte XXIII’te kız sözcüğü bugünkü anlamıyla 'kız' (mädchen) olarak anlamlandırılmıştır. Yalnızca bu anlamını gördüğümüz metinde "A064, A069, Bo29, Bo34, Bo58, G173, G185, G197, G210, G221, G255, G350, Ho75, H111, H232" satırlarında(Zieme 2005) transliterasyon karşıllğı olarak qyz harfleriyle gösterilmiştir. Aynı şekilde ünlü ile gösterim Berliner Turfan Texte 8'de de "A233, A234 (2 kez), A236, A249" satırlarında qüz biçimiyle aktarılııştır(Kara, Zieme 1977). Berliner Turfan Texte XXV'te “o017, 0289, 0292, 0546” satırlarında 'kı evlat' (tochter) anlamında kullanılmıştır(Wilkens 2007).

Türkische Turfantexte X'da qïz biçiminde “404, 454, 455, 459, 464, 471, 472, 475, 489, 524, 535, 537(?), 543, 544, 560, 563. satırlarda verilen sözcük, 'kız evlat, bakire, kız' (tochter, jungfrau, mädchen) olarak anlamlandırılmıştır(Gabain 1959:48). TT VI'da 5. satırdaki qïzgaq 'eli sıkı, paragöz' anlamıyla kullanılmasının dışında '105, 106, 107, 124, 309, 311, 343, 344, 347' satırlarında geçen qïz sözcüğü 'kız' (mädchen) anlamında kullanılmıştır(Gabain vd 1972). TT VII'de 13. '54'; 17. '24'; 18. '5,38,41'; 26. '3', 27. '4'; 28. '25' 33. '13'; 36. '11'; 39. '6'; 40. '23, 35, 50, 55, 66, 137, 396' sirasiyla bölüm ve satırlarında qïz olarak aktarılmış, ve 'kız' (mädchen) olarak anlamlandırılmıştır(Arat vd 1937).

Altun Yaruk'ta iki ayrı anlamda da kullanımı bulunmakla birlikte aç kız (89/21, 210/3, 236/1, 332/4, $341 / 18,397 / 17,399 / 18,401 / 13,405 / 15,422 / 2,434 / 16,514 / 11,552 b / 21,557 / 5,566 / 7)($ Kaya 544:1994) (açlık, kıtlık), ifadesinin ikileme olarak kullanıldığı görülmektedir.

Altun Yaruk’un tamamında ikinci anlamıyla yukarıdaki şekilde ikileme olarak geçen kız sözcüğü, bu metnin X. kitap çalışmasında ķz sözcüğü kız, kız evlat olarak anlamdırılmakla birlikte qyz, قز biçiminde aktarılmıştır(Gulcalı 2015:377). Aynı eserin III. kitap çalışmasında ise ḳzsız maddesi için 'tok, gözü tok (herhangi bir şeye gereksinimi olmayan)' anlamı verilmiştir(Ölmez 1991:99). Altun Yaruk IV. Tegzinç üzerine yapılan çalışmada sözcük tek madde başında iki anlamlı olarak verilmiştir(Tokyürek 881). Bununla birlikte 218, 854, 3222, 3457 (kitlık) satırları ve 2763, 3357 (kı) satırlarının tamamının transliterasyonu ünlülü (qyz) verilmiştir(Tokyürek 2018:339, 382, 509, 539, 548, 556).

Uygurca metinlerden Kuanşi İm Pusar'da 77. satırda kıı sözcügü 'kı evlat' anlamında kullanılmıştır(Tekin 2019a:42). Maytrisimit’te iki ayrı madde başında ḳz: hasis (cimri), kısa; ḳz: kız (Tekin 2019b:410) anlamları verilerek alınmıştır. 
İyi ve Kötü Prens Öyküsü çalışmasında qız maddesi için 'kız' anlamı verilmekle birlikte sözcüğe ilişkin “Bang “NegVerb” s. 114, n. 3'te qurqin ve qīz kelimelerinin 'kırmak, bozmak' anlamındaki qır- fiilinden geldiğini düşünüyor (?).” notu paylaşılmıştır(Hamilton 2011:185).

Manihaist Uygurların tövbe duası metni olan Huastuanift'te puşi bergäli kızganıp (Özbay 2014:87) ifadesi 'sadaka vermekten kaçınıp'(Özbay 2014:94) biçiminde aktarılmış ve kızgan- fiili için 'kıskanmak, cimrilik etmek’ anlamı verilmiştir(Özbay 2014:150).

Uygurca Oğuz Kağan Destanı'nda 55, 57, 59, 73, 74. satırlarda kız anlamıyla geçerken (688,690) 120. satırda 'nadir' anlamında kullanılmıştır(Bang Arat 1932:688,692). Metnin transliterasyonunda sözcük, qyz (ünlülü olarak) biçiminde yazılmıştır(Ağca 2019:77, 81).

Atabebü'l Hakayık'ta 444. ve 480. beyitlerde kız ve kızraḳ sözcügü nadir anlamında kullanılmakla birlikte (Arat 2006:76, 78, 98, 99) (Arat 2006:C43, C46) şeklinde yazılmıştı̀.

Kutadgu Bilig' te ḳz sözcüğü 'kız, kız çocuk' anlamında(Arat 254:1979b) 56, 75, 77, 399, 400, 564, 564, 1163, 1164, 1166, 1166, 1223, 1225, 1226, 1228, 1486, 1494, 1494, 1495, 2278, 2280(cariye), 2380, 2403, 3371, 3373, 3377, 338o, 3382, 3384, 3387, 3388, 3389, 3391, 3439, 3582, 3583, 3784, 3948, 44774504 , 4505, 4506, 4507, 4510, 4511, 4885, 4967, 5158, 5291, 5487, 5827, 6122, 6215, 6385, 6491. beyitlerde kullanılmıştır. Sözcük, 'pahalı, nadir' anlamlarında(Arat 254:1979b) 564, 564, 565, 866, 869, 1247, 1724, 3544, 6467. beyitlerde kullanımıştır(Arat 1979). Bu anlamda kullanılanların 'insan, gerçek, hayatın her günü, inanılacak kimse' sözcük ve sözcük gruplarını sırasıyla 'aziz, kıymetli, nadir' olarak nitelemesi(Arat 1988) dikkate değer bir konudur.

Bunlardan 564 ve 6122 numaralı beyitlerin üzerinde durulması gerekir:

564 bu mundag kişiler bolur idi ḳz bu ḳz ḳzhlı̣ ḳldı ḳz atı ḳz (Arat 1979:71)

564 Bu gibi insanlar çok nadir olur; nadirliğinden dolayıdır ki, nadire kız adı verilmiştir. (Arat 1988:51)

Yukarıdaki beyitte yapılan söz sanatı gereği sözcük için kökteş veya çok anlamlı olduğu sonucu da çıkabilir. Bu beyitten anlaşılan bu ikiliğin Yusuf Has Hacib'çe farkında olunduğu ve sanatlı söyleyiş için kullanıldığıdır.

Kaşgarlı'nın verdiği bilgiye göre; kīz kız : kız 5/3, 157/136, 164/142, 192/164, 208/178, 402/313, 404/314, 405/315, 433/339, 494/396, 533/434, 558/460, 559/461, 571/470, 576/473, 622/517, -rg: 269/236, 277/241, 621/516, -ka: 417/328, -lar: 376/296, -laşu: 377/297 "cariyesine" kızlaş- yerlerinde geçmektedir.

Hem uzun hem kısa ünlülü yazılan madde başlarının geçtiği yerleri vermek fonetik durumu görebilmek adına isabetli olacaktır.

5/3: Dîvânu Lugâti’t Türk çalışmasının giriş kısmında Türkçedeki durumları bilinsin diye kullanımda olan ve olmayan kelimelere verilen örneklerde kīz : 'kız' (kullanılmakta) bilgisi verilmiștir (Ercilasun vd 2018:3).

157/136 kīz örgüçlendi 'kızın saç örgüsü örüldü’(Ercilasun vd 2018:136)

164/142 (kız) kız nḍ ’pahalı şey' Örnek: Bu at kız aldım ‘bu atı pahalı aldım. 
$k ı z$ : kız; cariye, kız kırkın : cariyeler.

kız: kız meniך kızım ‘benim kızım'.

(ev kızı) 'bakire kıza ev kızı denir; evde kalan (kocaya gitmemiş) kız demektir. yinçge kız 'odalık'. Bu isim (kız), hem hür kız için hem de satın alınmış cariye için kullanılır. Asıl anlamı 'bakire'dir.

kzz kuş : üzerine konacakmış gibi insana doğru gelen bir kuşun adı.

167/144 Aynı madde başı için; 'kız kuş: renk bakımından ispinoza benzeyen bir kuşun adı' tanımı da bulunmaktadır(Ercilasun vd. 2018:144).

(kız) kız kişi : Argu lehçesinde cimri insan. Ata sözü: Kız kişsi sawı yōrıgl bolmas. Anlamı şudur: Cimrinin şöhreti yaygın olmaz, yayılmadan kalır(Ercilasun vd. 2018:142)

192/164 kapak: kızlık zarı - Kız kapakı sīdı 'kızlı̆̆ı bozuldu'

208/178 ardı sini kìz bodı anı̀ tāl

yaylir anıı artuçı burnı takı kıwal

bir kızı tasvir ederek diyor ki Bedeni körpe vücudu nazlı nazlı salınan, ardıç dalı gibi titreyen, burnu biçimli kız seni aldattı (Ercilasun vd. 2018:178)

269/236 er kīzıg basdı 'adam kızı bastı, üstüne çıktı(Ercilasun vd. 2018:236)

277/241 er kīzıg kıldı 'adam kız ile cima etti'(Ercilasun vd. 2018:241)

376/296 kīzlar kopzaşdı 'cariyeler ut çalmada yarıştılar'(Ercilasun vd. 2018:296)

377/297 ol meniๆ birle ok attı kızlaşu ‘o, benimle ok atmada yarıştı ve ortaya cariye sürdü’(Ercilasun vd. 2018:297)

402/313 kīz krrtışlandı 'cariyenin parlaklı̆̆ı ve yüzünün tazeliği güzelleşti'(Ercilasun vd. 2018:313)

404/314 kiz monçaklandı 'kız boncuk ve takı sahibi oldu'(Ercilasun vd. 2018:314)

405/315 kiz bökseglendi 'kzzın memesi tomurdu'(Ercilasun vd. 2018:315)

417/328 ol kizka kidiz sırıttı 'o, keçeyi kıza sıkıca ve büktürerek teyellettirdi'(Ercilasun vd. 2018:328)

433/339 kīz körketti 'kızın yüzü ve rengi güzelleşti'(Ercilasun vd. 2018:339)

494/396 kzz būt urdı 'kiz onu taktı'(Ercilasun vd. 2018:396)

533/434 kiz kesmelendi 'kız kendine perçem ve lüle yaptı'(Ercilasun vd. 2018:434)

558/46o kiz büdidi 'cariye vb. dans etti'(Ercilasun vd. 2018:460)

559/461 kiz saçın taradı 'kız saçını tarad’'(Ercilasun vd. 2018:461)

571/470 kĩz yinçü tolgadı 'kız inci vb. şeylerden yapılmış küpe takındı'(Ercilasun vd. 2018:470)

576/473 kiz çigin çignedi 'kız altın iplikle ipekli kumaş üzerine tasvirler dikti'(Ercilasun vd. 2018:473)

621/516 ol kizzıg sizillendi 'o, kızı kızkardeş edindi'(Ercilasun vd. 2018:516)

622/517 kiz yalıpuladı 'kız vb. -daha önce açılanan- iki iple oynadı(Ercilasun vd. 2018:517)

kiz : gelin, bakire gelin 148/129, 238/207, 606/498, -ıg: 560/462, 592/485

kīz : kadın $588 / 482$

xīz : Halaçlardan bir tabakanın ağzında kız 541/442 (Ercilasun vd 2018:654)

kīzkıya : küçük kız 519/418 (Ercilasun 2018:718)

kizzlan- : (cariyeyi) kzzlardan saymak 531/432

kıza- : bekareti bozmak (s 718)

-di 560/462, -mak 560/462, -r 560/462 (s 718)

kızlan- : kız çocuğu evlat edinmek

$-d \imath$ 391/306, 393/307, -mak 391/306, -ur 391/306

kızlan- : pahalı saymak 
-d 391/306, 531/432, 532/432, -mak 391/306, - ur 391/306

kızlaş- : yarışta ortaya cariye sürmek, cariyesine yarışmak

-mak 377/297, -ur 377/297

kızu- : pahalılaşmak-d 560/462, -mak 560/462, -r 560/462

kırkın : kız, cariye 164/142, 323/263 (Ercilasun vd 2018:714)

kırnak : cariye 238/206 (Ercilasun vd 2018:714)

kırt : kötü huylu, cimri 172/148 (Ercilasun vd 2018:714)

Ercilasun ve Akkoyunlu neşrinde görüldüğü üzere ağırlıklı olarak uzun ünlülü biçimin 'dişi’ manasında normal ünlülü yazımın 'pahalı, kıymetli' manasında yazıldığı görülmektedir; ancak bu durum: "Kaşgarînnin kzz sözcüğünün bir anlamının da 'değerli' olduğunu bildirmesi, Eski Türk toplumunda kzz’n birçok yönden kıymet arz eden ve bu sebeple korunan bir sıfata işaret ettiğini göstermesi bakımından dikkat çekicidir.(Berbercan 2017:14).” biçiminde yorumlanabilmektedir. Bu noktada fonetik durum göz ardı edilerek bağlama dayalı çıkarımlar yapıldığı açıktır.

Dankoff ve Kelly'nin çalışmasında qız: cimri, değerli, pahalı anlamı verilirken qīz için kız, bakire, kız (özgür ya da köle), kız çocuğu, bakire, cariye anlamları verilmiştir. bunun yanında qīz quş ifadesi bir kuş türü olarak aktarılmıştır(1985:139).

Mukaddimetü'-Edeb’te ḳız sözcüğü iki ayrı madde başında verilmiştir. İlki 'kız'(72-8, 73-5, 77-3, 196-7, 144-6, 144-6); ikincisi 'pahalı'(131-6, 60-7) anlamında kullanılmıştır(Yüce 2014:145). Bunlardan ilki ḳz biçiminde transkribe edilirken ikincisi $k$ lı biçiminde (altında nokta olan 1 harfiyle) transkribe edilmiştir. Çalışmanın sonunda "altında bir nokta bulunan ünlü Arap harfli metinde yazılmamıştır." notu düşülmüştür(Yüce 2014:229). Bu durumda ilk ḳı sözcügü Arap harfli metinde ünlüsüyle birlikte yazılmıştır. Nehcü'l-Feradis'te ḳz sözcüğü 'kız, kız çocuk, huri'(Ata 2014:240) anlamlarında kullanılmıştır. Yüzden fazla yerde geçen sözcüğün Arap harfli yazımında ' 1 ' ünlüsü kullanılmıştır(Eckmann 2014). Mu'înü'l-Mürîd'te kı̣z sözcüğü; 259/2, 261/1, 71/4, 173/3 bölüm ve satırlarında geçmiş ve 'kız, kız çocuğu' anlamlarında kullanılmıştır(Toparlı vd 2018:233). Sözcüğün geçtiği yerlerde Arap harfli yazımı ünlülüdür(Toparlı vd 2018:300, 310, 323). İbnü Mühenna Lügati’nde ḳz sözcüğü 'kız' ve 'pahalı' anlalarında kullanılmıştır(Karagözlü 2018:291). Metinde 119B, 8'de geçen kız anlamındaki $k z z$ ünlülü yazılırken 126A, 7'de geçen 'pahalı' anlamındaki $k z z$ ünlü kullanılmadan yazılmıştır(Karagözlü 2018:391,397). Kutb’un Husrav u Şīīin’inde ḳ:z biçiminde madde başı olarak alınan sözcüğe 'kız' olarak anlam verilmiştir(Demirci vd 2014:321)..

\section{Değerlendirme}

Öncelikle bugünkü Türk lehçelerinden Türkmen Türkçesi ve Yakut Türkçesinde sözcüguün uzun ünlülü biçimini koruduğu göz önünde bulundurulmalıdır. Uzun ünlülü olmasının aslî biçim olarak değerlendirilebileceği bu bağlamda düşünülebilir.

Sözcüğün Tonyukuk yazıtında $\mathrm{lk}$, kı sesbirimlerini karşlayan (Q) runiformunun yanında ı,i sesbirimleri için (P) kullanılan runiformu da eklemesi Orhon Türkçesinin ses yönünce ünlü uzunluğu olduğunun göstergesi sayılır. Bunun yanında Şine Usu'da ve Yenisey'de görüldüğü üzere çoğunlukla sözcük ünlülü (ZPZ) yazılmıştır.

Eski Uygur metinlerinde sözcügün sözü edilen iki anlamı da taşıyor olması, anlam genişlemesine Karahanlı Türkçesi döneminde uğradığı savını da geçersiz kılmaktadır. Bunun yanında ağırlıklı olarak 
sözcük, 'kız, kız evlat' anlamında ve ünlülü biçimde kullanılmıştır. Eski Uygur Tükçesinde qızgaq, kızsız, qızgan- diye geçen 'cimrilik, etmek, tokgözlü paragöz, sadaka vermekten kaçınmak' anlamlarına gelen sözcüklerin kökünün farklı olması da muhtemeldir.

Karahanlı Türkçesi döneminde ikinci anlamın kullanımı devam etmekle birlikte öne çıan 'dişi' anlamında kullanımıdır. Atabetü'l-Hakayık'ta yalnızca ikinci anlamıyla kullanılmıştır. Kaşgarlı'da sözcüğün kullanımında ünlü uzunluklarının dikkate alındığı görülmektedir. Hatta bunlardan Dankoff ve Kelly'nin çalışmasında ünlülerin kullanımına göre sözcüklerin net bir biçimde ayrıldığı görülmektedir. Kaşgarlı'daki bu ayrım, kendinden önceki dil yadigarlarındaki ünlü kullanımı ya da uzunluğuna ilişkin verileri yeniden ele almayı gerektirmektedir.

Mukaddimetü’-Edeb’te ḳız sözcüğünün 'dişi’ manasında olanı ünlülü pahalı manasında olanı ünlü olmadan yazılmıştır. İbnü Mühenna Lügati’nde de aynı durum mevcuttur. Bunun yanında Nehcü'lFeradis, Mu'înü’l-Mürîd’te yalnızca 'kız' anlamına gelen örnekler ünlülü yazılmış, Kutb’un Husrav u Şīīin’inde "i” uzun ünlülü verilmiştir.

Eski Türkçe döneminde sık kullanılan 'kız' sözcüğünün kökteş olma durumu göz önündedir. İki ayrı gösterge Türk dilinde ünlü uzunluklarıyla ayırt edilebilir. Bu durum zamanla ortadan kalkıp iki ayrı sözcüğün bir sözcükmüş gibi algılanmasına sebep olabilir. Üstelik semantik bakımdan farklı anlamlar bir ölçüde de olsa aynı küme içinde değerlendirilmeye müsait ise bu algı daha da güçlenir.

\section{Kaynakça}

Aksan, D. (1975). Eşanlamlılı Sorunu ve Türk Yazı Dilinin Eskiliğinin Saptanmasında Eşanlamlılardan Yararlanma, 1. Türk Dili Bilimsel Kurultayına Sunulan Bildiriler, 1972, 531542.

Aksan, D. (2017). Anlambilim. Ankara : Bilgi.

Arat, R. Bang, W. (1932). Die Legende Von Oguz Kagan. Berlin: Verlag Der Akademie der Wissenschaften.

Arat, R. R. (1937), Türkische Turfan-Texte VII. Von Dr. G. R. Rachmati. Berlin : Mit sinologischen Anmerkungen von Dr. W. Eberhard.

Arat, R, R. (1979a). Kutadgu Bilig I Metin. Ankara : Türk Dil Kurumu.

Arat, R, R. (1979b). Kutadgu Bilig III İndeks, İndeksi Neşre Hazırlayanlar: Kemal .Eraslan, Osman F. Sertkaya, Nuri Yüce. Ankara : Türk Kültürünü Araştırma Enstitüsü.

Arat, R, R. (1988). Kutadgu Bilig II Çeviri (4. baskı). Ankara : Türk Tarih Kurumu.

Arat, R, R. (2006) Atabetü’l-Hakayık. Ankara : Türk Tarih Kurumu.

Aydın, E. (2017). Orhon Yazıtları, Köl Tegin, Bilge Kağan, Tonyukuk, Ongi, Küli Çor. İstanbul: Bilge Kültür Sanat.

Aydın, E. (2018). Uygur Yazıtları. İstanbul : Bilge Kültür Sanat.

Aydın, E. (2019). Sibirya'da Türk İzleri - Yenisey Yazıtları. İstanbul : Kronik.

Berbercan, M, T. (2017). İslam Öncesi Türk Metinlerinde 'Kız' ve ‘Kadın', Journal of Old Turkic Studies, 1/1, 2017: 7-19.

Clauson, G. (1972). An Etymological Dictionary of Pre- Thirteenth-Century Turkish, Oxford University Press.

Dankoff, R.; kelly, J. (1982-85). Compendium Of The Turkac Dialect, I-III, Harvard University Printing Office. 
Demirci, Ü, Ö, karslı, S. (2014). Kutb’un Husrav u Şīin̄’i - Dizin. İstanbul : Kesit.

Eckmann, J. (2014). Nehcü’l-Ferâdîs, Yayımlayanlar: Semih Tezcan, Hamza Zülfikar, DizinSözlük: Aysu Ata, Ankara: Türk Dil Kurumu.

Ercilasun, A. B. - akkoyunlu, Z. (2015). Kaşgarh Mahmud, Dîvânu Lugâti’t-Türk, Giriş-Metin-ÇeviriNotlar-Dizin. Ankara: Türk Dil Kurumu.

Esin, E. (1985). Kotuz: İkinci Kök-Türk Sülalesinin Tamgası, Erdem, 1: 125-131.

Gabain, A. von. (1959). Türkische Turfantexte X, Das Avadāna des Dämons Ātavaka, Bearbeitet von Tadeusz Kowalski. Berlin : Aus dem Nachlaß herausgegeben Akademie Verlag.

Gabain, A. von vd. (1972). Türkische Turfan-Texte VI. Leipzig : Sprachwissenschaftliche Ergebnisse der Deutschen Turfan-Forschung. Band 2.

Gulcalı, Z. (2015) Altun Yaruk Sudur X. Kitap, T.C.Yıldız Teknik Üniversitesi Sosyal Bilimler Enstitüsü Türk Dili ve Edebiyatı Ana Bilim Dalı (Basılmamış Doktora Tezi), İstanbul.

Kara, G, Zieme, P. (1977). Die uigurischen Übersetzungen des Guruyogas „TieferWeg“e von Sa-skya Pand ita und der Mañjušīnāmasam gīti. Berlin : Schriften zur Geschichte und Kultur des Alten Orients. Berliner Turfantexte 8.

Karagözlü S. (2018). İbnü Mühennâ Lügati. İstanbul : Kesit.

Li, Y, S. (1999). Türk Dillerinde Akraballk Adları. İstanbul : Simurg.

Nadelyayev, V. M. / Nasilov, D. M. / Tenișev, E. R. / Sçerbak, A. M.,(1969), Drevnetyurkskiy Slovar'. Leningrad: Nauka.

Ölmez, M. (1991). Altun Yaruk III. Kitap (5. Bölüm), Türk Dilleri Araştırmaları Dizisi 1, Ankara.

Özbay, B. (2014). Huastuanift Manihaist Uygurlarn Tövbe Duası. Ankara : Türk Dil Kurumu.

Sertkaya, O, F. (1995). Tonyukuk Abidesi Üzerine Üç Not: Tonyukuk Abidesindeki Kız-Koduz Sifat Tamlaması Üzerine, Göktürk Tarihinin Meseleleri. Ankara : TKAE.

Tekin, Ş. (2019a) Kuanşi İm Pusar, Uygurca Metinler I. Ankara : Türk Dil Kurumu.

Tekin, Ş. (2019b) Maytrısimit, Uygurca Metinler II. Ankara : Türk Dil Kurumu.

Tekin, T. (1995). Türk Dillerinde Birincil Uzun Ünlüler, Türk Dilleri Araştırmaları Dizisi:13, Yayımlayan: Mehmet Ölmez. Ankara : Simurg.

Tokyürek, H. (2018). Altun Yaruk Sudur IV. Tegzinç. Ankara : Türk Dil Kurumu.

Toparlı, R, Argunşah, M. (2018). Mu'înü’l-Mürîd. Ankara : Türk Dil Kurumu.

Wılkens, J. (2007). Edition des alttürkisch-buddhistischen Kşanti Kılguluk Nom Bitig. Berlin (Berliner Turfan-Texte XXV).

Ylldırım, A. (2020). Yenisey Yazıtlarında Akrabalık Adlar, Journal of History School, 46, 1763-1783.

Ylldırım, F. (2017). Irk Bitig ve Orhon Yazıl Metinlerin Dili. Ankara : Türk Dil Kurumu.

Zieme, P. (2005), Berliner Turfantexte XXIII: Magische Texte des uigurischen Buddhismus. Mit 193 Abbildungen auf 95 Tafeln, Turnhout: Brepols. 